This item was submitted to Loughborough's Research Repository by the author.

Items in Figshare are protected by copyright, with all rights reserved, unless otherwise indicated.

\title{
Bridging the macro-micro divide: using an activity theory model to capture socio-cultural complexity in mathematics teaching and its development
}

PLEASE CITE THE PUBLISHED VERSION

http://dx.doi.org/10.1007/s10649-009-9190-4

\section{PUBLISHER}

(C) Springer Science + Business Media B.V.

\section{VERSION}

AM (Accepted Manuscript)

\section{LICENCE}

CC BY-NC-ND 4.0

\section{REPOSITORY RECORD}

Jaworski, Barbara, and Despina Potari. 2019. "Bridging the Macro-micro Divide: Using an Activity Theory Model to Capture Socio-cultural Complexity in Mathematics Teaching and Its Development". figshare. https://hdl.handle.net/2134/8799. 
This item was submitted to Loughborough's Institutional Repository (https://dspace.lboro.ac.uk/) by the author and is made available under the following Creative Commons Licence conditions.

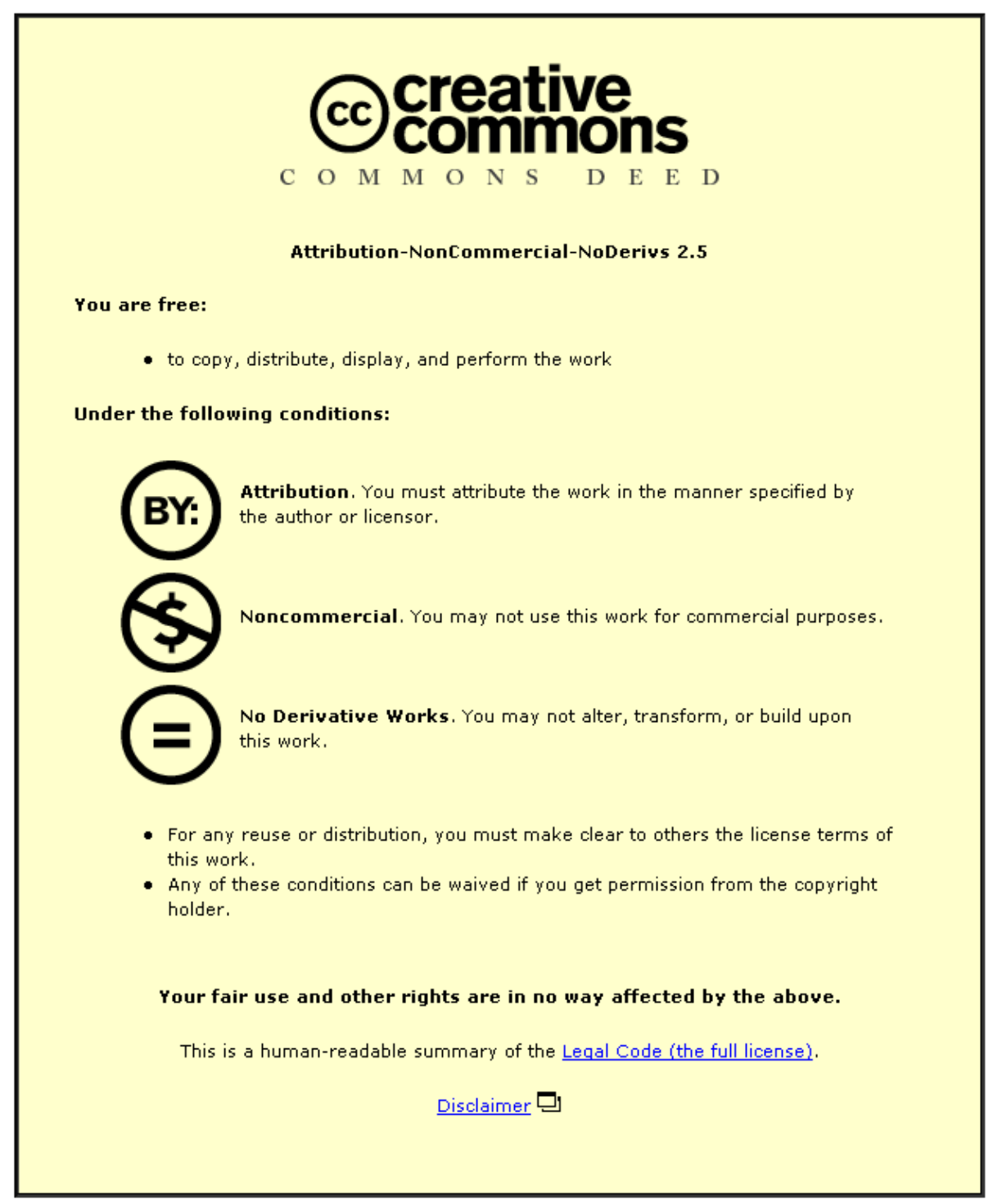

For the full text of this licence, please go to: http://creativecommons.org/licenses/by-nc-nd/2.5/ 
Title:

Bridging the macro-micro divide: using an activity theory model to capture socio-cultural complexity in mathematics teaching and its development.

Authors

Barbara Jaworski

Loughborough University, UK

Corresponding author:

Barbara Jaworski

b.jaworski@lboro.ac.uk

Professor Barbara Jaworski

Mathematics Education Centre

Loughborough University

Loughborough

LE11 3TU

\author{
Despina Potari \\ University of Athens, Greece
}

Tel: +44 (0) 1509228254

Fax: +44 (0) 1509228211

\section{Abstract}

This paper is methodologically based, addressing the study of mathematics teaching by linking micro and macro perspectives. Considering teaching as activity it uses Activity Theory and in particular the Expanded Mediational Triangle (EMT) to consider the role of the broader social frame in which classroom teaching is situated. Theoretical and methodological approaches are illustrated through episodes from a study of the mathematics teaching and learning in a Year 10 class in a UK secondary school where students were considered as 'lower achievers' in their year group. We show how a number of questions about mathematics teaching and learning emerging from microanalysis were investigated by the use of the EMT. This framework provided a way to address complexity in the activity of teaching and its development based on recognition of central social factors in mathematics teaching-learning.

Keywords:

Mathematics teaching; teaching as activity; activity theory; expanded meditational triangle; Macroanalysis; Microanalysis; Teaching Triad. 


\section{Bridging the macro-micro divide:}

\section{using an activity theory model to capture socio-cultural complexity in mathematics teaching and its development.}

\author{
Barbara Jaworski \\ Loughborough University, UK
}

Despina Potari

University of Athens, Greece

This paper is methodologically based, addressing the study of mathematics teaching by linking micro and macro perspectives. Considering teaching as activity it uses Activity Theory and in particular the Expanded Mediational Triangle (EMT) to consider the role of the broader social frame in which classroom teaching is situated. Theoretical and methodological approaches are illustrated through episodes from a study of the mathematics teaching and learning in a Year 10 class in a UK secondary school where students were considered as 'lower achievers' in their year group. We show how a number of questions about mathematics teaching and learning emerging from microanalysis were investigated by the use of the EMT. This framework provided a way to address complexity in the activity of teaching and its development based on recognition of central social factors in mathematics teaching-learning.

\section{Introduction}

How is mathematics teaching related to the learning of the students for whom it is designed? What are the factors that impinge on teaching design and the development of teaching for effective learning? We are interested in studying relationships between teaching approaches and practices and students' learning in mathematics classrooms. Two focuses emerge centrally from such aims:

(1) relationships between student and teacher interactions and cognitions, and associated issues determined from classroom dialogue (micro-analysis); 
(2) relationships between classroom interactions and cognitions and the wider sociosystemic cultures through which learning is mediated (macro-analysis).

In our earlier work we discussed the use of the Teaching Triad (comprising elements of management of learning (ML), sensitivity to student(SS) and mathematical challenge $(M C))$, a theoretical tool emerging from research by the first author (Jaworski, 1994), both to analyse teaching and to guide teaching. Our Teaching Triad Project (TTP) considered uses of the triad both as a developmental tool, enabling and promoting teacher reflection and development of teaching, and as a tool for analysing teaching-learning interactions (Potari \& Jaworski, 2002). Micro-analysis of teacher-student interactions, triangulated with data from interviews with teachers, allowed access to finer details of learning and cognition in classrooms both of teachers and of their students. Here, we illustrate how we go beyond findings of the micro-analytical process in order to focus more specifically on social situations and concerns, a process of macro-analysis, using a framework or model based in activity theory.

\section{Methodological background}

The Teaching Triad Project (TTP) involved 4 participants, two teacher-researchers (Jeanette and Sam) and two university researchers (ourselves). The teachers, who had been researchers with one author in a previous project (Jaworski, 1998), wanted to use the triad to think further about developing their teaching. The university researchers wanted to study the teachers' engagement with the triad and to gain further insights into the use of the triad for analysing teaching (Potari \& Jaworski, 2002). 
Data, in the TTP, were collected, using audio recording and transcription, from classroom observations of mathematics lessons taught by the teachers, interviews with teachers before and after each lesson, interviews with students once towards the end of the project, and periodic meetings between the four partners. Field notes were kept during every classroom observation by one researcher who sat with one pair of students or an individual student for the whole lesson. This allowed us to study the interactions of the teachers with these students both in the whole class teaching and while the students were working on a task posed by the teacher. Teachers were also interviewed after reading accounts from initial analysis of episodes from the above data. In this current paper, we exemplify and explain our analytical process using data from Sam's teaching with emphasis on how broader social issues can be addressed to expand micro analyses and address teaching-learning ${ }^{1}$ complexity.

\section{Embedding analysis in an activity theory perspective}

\subsection{Social dichotomies in teaching and learning mathematics.}

Recent decades in mathematics education research have seen a move to study individual learning within its social setting often with an emphasis on language or tools that support learning (Lerman, Xu, \& Tsatsaroni, 2002; Seeger, Voigt \& Waschescio 1998). Kieran, Forman and Sfard (2001) challenge "a problematic dichotomy between the individual and social research perspectives" - that has been "worrying researchers for some time" (p.9), suggesting that

\footnotetext{
${ }^{1}$ We follow Bartolini Bussi (1998) in using "teaching-learning" as a unifying concept in addressing activity in classroom situations.
} 
... the cognitivist ('individualistic') and interactionist ('social') approaches are but two ways of looking at what is basically one and the same phenomenon of communication, one that originates between people and does not exist without the collective even if it may temporarily involve only one interlocutor.

In some studies of classroom interaction, the social dimension has been seen in terms of intersubjectivity between participants (Cobb, Yackel \& Wood, 1992; Jaworski, 1994; Steinbring, 1998; Voigt, 1996), a position which has also been criticised as limiting analysis (Daniels, 2001). Daniels (p.86) cites Wertsch and Lee (1984) who "argue that many of the psychological accounts which attempt to discuss factors beyond the individual level "tend to equate the social with the intersubjective"" A criticism is that the research focus stays within the interaction itself and does not address wider sociological factors with respect to which the interaction is meaningful.

However, intersubjectivity can be seen as deeply sociocultural in its manifestations - "a function of the setting, the activity, the actors, the texts, and so on" (Lerman, 1996, p.137). Lerman writes,

I am arguing that we need an integrated account, one that brings the macro and micro together, one that enables us to examine how social forces such as a liberalprogressive position, affect the development of particular forms of mathematical thinking (Lerman, 2001, p. 89).

He cites Wertsch, del Rio and Alvarez as follows:

The goal of a sociocultural approach is to explicate the relationships between human action, on the one hand, and the cultural, institutional, and historical situation in which this action occurs, on the other. (Wertsch, del Rio \& Alvarez ,1995, p. 11, cited in Lerman, 2001, p. 96)

A unit of analysis between systems and structures on the one hand and daily classroom practices on the other is suggested by Engeström (1998) who points towards "the middle level between the formal structure of school systems and the content and 
methods of teaching" (p. 76). This middle level of analysis (referred to as "the hidden curriculum", ibid) includes

grading and testing practices, patterning and punctuation of time, uses (not contents) of textbooks, bounding and use of the physical space, grouping of students, patterns of discipline and control, connections to the world outside school, and interactions among teachers as well as between teachers and parents (ibid).

For example, in the episodes to which we refer below, identification of the problems that two students face in developing the understanding of mathematical concepts desired by their teacher leads to a questioning of school and educational systems (including curriculum and evaluation practices, grouping practices within schools) as well as the social space of friends and family in national economic and political systems.

\subsection{The concept of activity}

Central to a sociocultural approach according to Van Oers (2001, p. 71), following Leont'ev's activity theory, is the concept of activity, which refers to "any motivated and object-oriented human enterprise, having its roots in cultural history, and depending for its actual occurrence on specific goal-oriented actions”. For example, Van Oers refers to mathematical activity as "an abstract way of referring to those ways of acting that human beings have developed for dealing with the quantitative and spatial relationships of the cultural and physical environment" (ibid).

Activity, as synthesized by Daniels (2001, pp.84/6) with reference to Davydov Leont'ev and Engeström, has some developmental function, is characterized by constant transformation and change, is guided by motive and is a collective and systemic formation that has a complex mediational structure. It is these characteristics that have attracted us to the notion of activity in providing a conceptual frame for analysis in our 
research. We are starting to see in mathematics education a wider use of activity theory in the educational context because of its power to deal with complexity in educational systems (Abboud-Blanchard, Cazes \& Vandebrouck, 2007; Bartolini Bussi, 1998; Seeger et al, 1998). An early use of activity theory in mathematics teaching and learning, relating the concept of activity to educational activity and influencing subsequent work, can be seen in the research of Christiansen and Walther (1986) whose focus was on the tasks developed or used by the classroom teacher and their influence on student learning.

In our study, we extend this focus on tasks to address the wider complexity of teaching-learning which includes tasks and the related macro social setting. We are undertaking, in the words of Engeström and Cole (1997), "concrete analyses of situated, practice-bound cognition" in which we want "both a collective and an individual perspective" (p. 304). Individual perspectives refer to cognition of learners: student as learner of mathematics, teacher as learner of mathematics teaching, developing teaching practice, and researcher as learner through the research process. In collective terms, we recognise individual learners as members of communities in which practices, understandings and awarenesses develop, and inter-relationships foster individual identity and agency.

We draw on Leont'ev's (1979) three tiered explanation of activity. First, human activity is always energised by a motive. Second, the basic components of human activity are the actions that translate activity motive into reality, where each action is subordinated to a conscious goal. Activity can be seen as comprising actions relating to associated goals. Thirdly, operations are the means by which an action is carried out, and are associated with the conditions under which actions take place. Leont'ev's three tiers 
or levels can be summarized as: activity $\leftarrow \rightarrow$ motive; actions $\leftarrow \rightarrow$ goals; operations $\leftarrow \rightarrow$ conditions, where the arrows indicate the two-way relationships involved (Jaworski \& Goodchild, 2006, p. 3.355).

Figure 1 follows Cole and Engeström (1993), Engeström and Cole (1997) and Engeström (1998) in representing "the modelling of human activity as a systemic formation" (Engeström \& Cole, 1997, p. 304). According to Engeström, the topmost of the subtriangles represents the visible instrumental actions of teachers and students, and therefore, in our terms, represents the space of microanalyses. He refers to this as the "tip of the iceberg" and adds that "the "hidden curriculum" is largely located in the bottom parts of the diagram: in the nature of the rules, the community and the division of labour of the activity" (Engeström, 1998, p. 79). We see these triangles as providing a more explicit framework to address complexity related to the broader social systems in which classroom activity is based (Valero-Dueñas, 2002). We demonstrate our use of these triangles in characterizing the macro issues in our study.

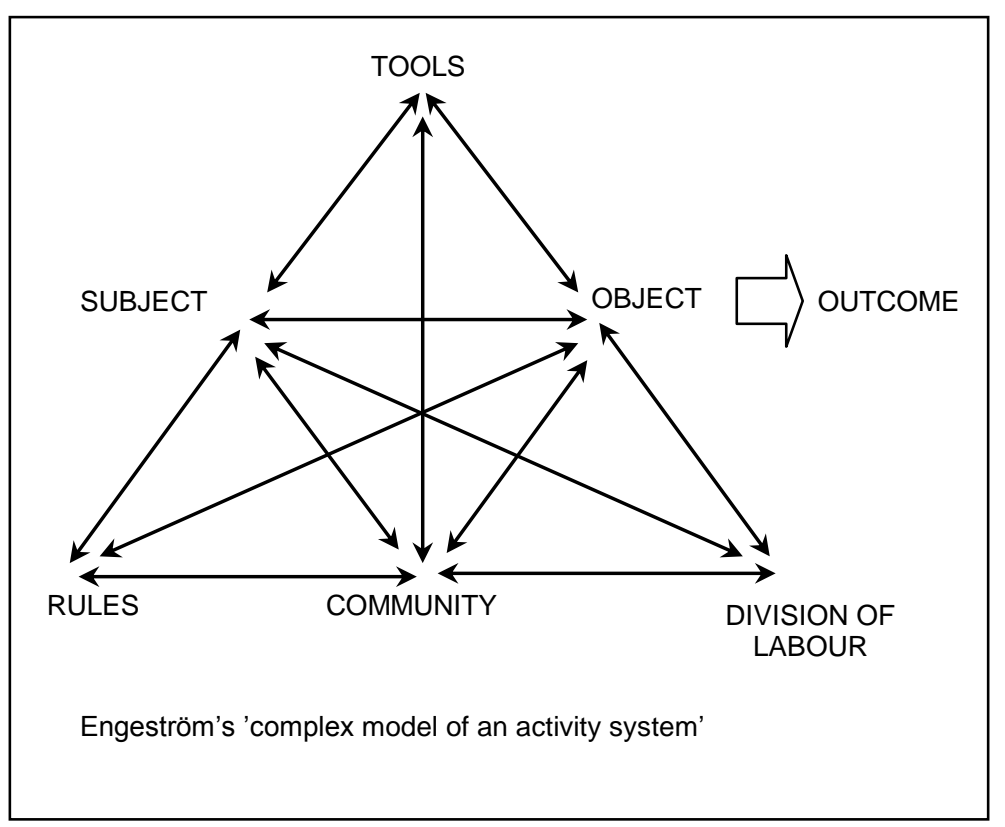


Figure 1: The basic mediational triangle expanded (Cole \& Engeström, 1993).

Using this expanded mediational triangle (EMT) "to represent the idea that activity systems are a basic unit of analysis ... provides a conceptual map to the major loci among which human cognition is distributed ... [and] ... includes other people who must be taken into account simultaneously with the subject as constituents of human activity

systems" (Cole \& Engeström. 1993, p. 8). The 'subject' in our case may be any teacher or pupil, or more probably differently configured groups of teacher and/or pupils, each with some object (or goal or objective) for their activity within the system. The arrows indicate dialectic relations among the various elements of the activity system.

In the Teaching Triad Project, the elements of the teaching triad (management of learning, sensitivity to students and mathematical challenge) were first employed to micro-analyse classroom interactions and recognise elements of mathematical challenge related to cognitive and affective sensitivity (as well as being employed as developmental tools by the teachers) (Potari \& Jaworski, 2002). Here we expand this focus, seeking what we called earlier a "macro-analysis". We recognise now that the macro necessarily includes the micro - an activity theory perspective allows us to reach for the broader, inclusive, picture. We illustrate this process through some episodes from our analyses.

\section{The teaching-learning context}

\subsection{School environment and teaching approach}

Sam was a very experienced mathematics teacher, highly regarded by school and colleagues. He was an enthusiastic mathematician, innovative in his approach to classroom activity and demanding of students in expecting that they would engage with 
mathematics in thoughtfully creative ways as he did himself. He had joined his current school as head of the mathematics department only one month before the TTP research began.

The school was a mixed secondary comprehensive school with a good reputation (e.g., for achievement and social order) in a small town in a rural area of England, largely middle class, with approximately 2000 students of ages $11-18$. It was organized into subject departments in which teachers were free to place students into teaching groups as they thought appropriate. In mathematics, students were grouped into sets relating to their achievement. 'Higher' sets usually had more students than 'lower' sets in order to give more individual teaching to "slower learners"2. The students of the Year 10 (Y10) class to which we refer were designated by the school mathematics department as a 'lower set', suggesting that these students were lower achievers than others in their year group. There were just 14 students in this set. We recognize that terminology here is neither socially neutral nor uncontentious: such issues will be addressed in our analyses.

At the time of this research, all students at the end of Year 11 (aged 16) had the opportunity to take the GCSE (General Certificate of Secondary Education) examination in any subject. In mathematics, there were three levels of examination: advanced, intermediate and foundation. Thus teachers had to decide, for any student, which level was appropriate; this was based on students' performance in their allocated sets throughout secondary schooling, and setting was influenced by this examination structure.

\footnotetext{
2 "Ability grouping in mathematics is deeply embedded into school practices and British traditions" Boaler and Wiliam (2001, p.80).
} 
Teaching in England is 'guided' by a National Curriculum which defines principles for the education of students both generally and in subject areas, the latter with varying degrees of specificity according to subject. In addition, in mathematics, a Numeracy Strategy offers a recommended format for lessons, a detailed set of recommended activities for teachers to use in the classroom, and expectations that students will engage with "homework" outside classroom hours. Schools and teachers are assessed by external inspectors relative to the curriculum and strategy. The observed teaching was conditioned and constrained by these structures and expectations.

Sam's approach to teaching was characterized by a combination of whole class teaching and individual or pair work. His main teaching goal was that his students should understand and be involved in doing mathematics and also develop mathematical skills. This applied to students at all levels, although he recognized a specific challenge with the Y10 class.

I try and get my lessons based on their understanding and I try to make that the focus of the lesson. And if it doesn't work, it's important and therefore I have to do something to make them understand ... Somehow I think it's not so easy with this Y10 to do that, they are not so easy. And also they are put in a bottom set, and having been put in that they are thinking, 'well ok we are not expected, we are not expected to think in this kind of way', and I really want to think that you [the student] can [think] , and I think some [students] do [think], you see; my worry is that some of them just turn off.

Analysis of our observations shows that Sam offered help and support to students by

- encouraging them to reflect on their actions,

- asking focused questions,

- encouraging them to make connections with their previous work;

- inviting them to contribute to whole class discussion; 
- asking for peer communication

- expressing his goals and leading the students towards them.

Often, individual help to a student took place as part of the whole class dialogue or was given in a short talk with a student, or a quick hint, while students were working individually or in pairs. What we saw little of was careful listening to students to make sense of their interpretations of the tasks with which they engaged.

Sam saw his strength as a teacher being in offering mathematical challenge at appropriate levels. He wanted to judge this more carefully with respect to sensitivity to students (cognitive and affective) needs. In practice, there were cases where the teacher's objectives differed from the students' needs and were unrealisable by the students so that tensions emerged. He talked of certain students, or groups of students, being 'resistant' to his teaching, while others worked 'productively'. We emphasize that these were the teacher's words and we use them in this spirit, rather than, for example, our own theorizing of resistance and productivity. Sam's research in the former project had been directed at exploring reasons for what he perceived as students' resistance (Jaworski, 1998). Our analyses, below, treat such tensions as central to a characterization of the social frame in which teaching-learning activity takes place and throw light on what the teacher saw as 'resistance'.

\subsection{Episodes from teaching in Y10 - details emerging from analysis}

For our purposes here we focus on three 70-minute lessons (out of 31 lessons that we observed of this teacher, 12 with the Y10 group) on statistics, where the focus was on "averages". These lessons highlighted the productivity/resistance dichotomy that was Sam's earlier focus of research. He structured these lessons in three parts, reviewing 
students' homework, introducing concepts and skills and then offering more 'challenging' activities related to the averages:

You can see there are three bits of this in a way. The first bit would be oral, getting them to read their homework. And the second bit would again just be making sure their concepts work and the third thing then was to give them this challenge ...

In these three lessons, the teacher had planned a didactical inquiry within our project in which he had designed tasks to address basic statistical ideas and resources relevant to his tasks. The students should explore the meaning of basic terms by looking them up in a dictionary and by matching with cards containing definitions and examples. They should calculate the averages of different sets of numerical data, construct their own numerical data for a given average, estimate if a number could be an average for a given set of data and calculate averages for a set of real data such as the pocket money of the students in the class. Defining, exemplifying, constructing, estimating, calculating, mathematizing were important mathematical processes in which students should be engaged. The teacher considered that in general to develop a meaning for the statistical terms was very important. Students should look critically at a result to see if it fitted the set of numbers from which it was calculated:

All the time I'm thinking, OK they can do this but do they understand it? .... You often see this with people when they find the average. It's got nothing, it's completely unrelated to the set of numbers they've got and yet they don't sit and they don't think, well this is wrong. They don't think that. And I want them to reflect on what they do.

From these lessons, we analyzed a series of episodes concerning the interaction of the teacher with a pair of students, Amy and Sarah. These episodes show the teacher's actions in facing the "resistance" of the two girls to his challenges. In our analysis we tried to gain insight to the nature of the teaching task and Sam's response to it. We 
illustrate the analytical process through consideration of three episodes from these lessons.

From the previous lesson, the teacher had set his students a homework task to look up, in a dictionary, definitions of the mathematical terms average, mean, median, mode and range. This homework was an example of a task designed to challenge students - in this case to start to see the meanings behind the mathematical terms and thus as a first step in understanding the concepts. He had also designed a second task, the cards task. involving sets of cards each containing either a definition or worked example related to the mathematical terms. The cards were designed to help students make links between terms, definitions and examples in order to foster conceptual understanding. Such design and innovation was typical of this teacher's approach to teaching as observed in the previous project. Before the first lesson he explained to researchers some of the details of his inquiry focus at this stage:

I've got lots of sets of them [cards]. I want to see how good they are. ... I'm going to get what they've [students have] found out from the dictionary first of all, and then I'm going to get them [students] to use them [the cards].

In the lesson, each pair of students would be given a set of cards and asked to identify the relevant average term with the definition and the example. One set of cards is shown in Appendix 1. 
Since a full micro-analysis of the three episodes ${ }^{3}$ would take more space than is available here, we offer a brief narrative account highlighting key elements supported by words from teacher or students.

\subsubsection{Episode 1: Students had not done the homework}

In the first lesson, some students indicated they had not done the homework; some had left their books at home, or had lost the paper the homework was written on, or did not have a dictionary. Eight of the fourteen students in the class, Sarah and Amy included, had not brought the required homework. Sam expressed his disappointment to the class as a whole, "My lesson plan for today has been completely destroyed because you have not done the homework". Various students said they did not have a dictionary. The teacher commented:

Some of you told me you don't have a dictionary, and I said, well you go to the library then. I'm surprised that you don't have a dictionary at home because I think it's really important that you have a dictionary.

Further, he said that those who had not done their homework would get "detention", according to school rules. This led to student complaints; some said that the task was too hard. The teacher responded:

You cannot tell me that you didn't understand it because it was a straightforward homework. Amy said to me that she didn't have a dictionary at home. I said fine, you have Tuesday, Wednesday, Thursday to go to the school library and you can just copy the words out of the dictionary ... my lesson was going to start with what you had done in your homework. The fact that more than half of you in this class have not done the homework means that it is going to have to be a different lesson [from the one planned].

\footnotetext{
3 Working turn by turn on a transcript of interaction, triangulating with interview and other data, and relating to the teaching triad (Potari \& Jaworski, 2002).
} 
Following the hiatus of this opening, the teacher asked the students who had done their homework to read to the class the definitions they found in the dictionary starting from the term "average". He gave dictionaries to some students so that they could look up terms. Students read what they had found in the dictionary; the teacher asked questions; and there was discussion about the meaning of what was written. He then distributed the cards and explained the cards task.

As the teacher subsequently listened in to Sarah and Amy's conversation, it became clear that the girls still had problems with the use of a dictionary. They thought the one he had given them was a French dictionary. The teacher said, "It's not French!" and the girls replied, "It is", "It is". They pointed to words they thought were French -- "abdicate, ablution, ...", and Sam responded "they're English words, they're not words that you use, but they're all English words. So, let's look up average". He showed them how to look up the words, read the dictionary definitions, and how to apply these definitions to what they read on the cards. They appeared to have extreme difficulty in understanding the task, and therefore in starting work on it.

\subsubsection{Episode 2: Getting Involved}

As the lesson progressed, Sam was busily moving between groups responding to many queries including those from Amy and Sarah. His style was a quick conversation, leaving students to work further themselves and then returning for further discussion. Amy asked him if their work was "right": there was discussion in which the teacher focused on the words and their meaning - "Median? What's it sound like?" -and an interchange about fitting words into the spaces in the cards. He acknowledged Amy's thinking, saying "you thought when you did that". Up to this point there had been a 
mixture of open and closed questions from the teacher. On his next visit to them, he asked, referring to mode, "Why is it called the mode, do you think?", a challenging question emphasizing thinking again, but Amy could not respond. So he told her, "mode and most, they sound the same". He then left her to decide how to continue. Returning, after about 2 minutes, when the girls appeared not to be working, Amy told him she didn't know what to do. The teacher then offered his own explanation of median, relating to Amy's own example, and was rewarded by her appearing to engage and understand. Referring to what she had written, she asked, "is that right then?" and he replied, "that's right”. She confirmed, “That one has to go there?", and he replied "Right. Thinking Amy. That's good". Teacher and student smiled at each other.

\subsubsection{Episode 3: Being involved}

During Episode 2, Sarah was gazing around the classroom, talking to others, not paying attention to the task or to Amy. After some time she returned to the task. The teacher was moving around the class offering help to pairs of students. At one point, he interrupted the class to suggest an extension to their work: that they might try to write their own examples of data sets related to the mathematical terms and calculate the value of the term. The girls were not sure about what they were supposed to do.

Returning to Amy and Sarah, the teacher said, "Pick your own set of numbers and see if you could do the same as I have done with the examples. Right?" The girls found it difficult and Sarah argued "I can't do that" The teacher showed her a specific set of numbers and asked her "what do you have to do with these?" referring to the ordering of numbers to get the median. Sarah asked, "How can we jump them around. How can we 
put this one there and that one there?" .The teacher asked "Does it make sense what you said to me?", and Sarah added "I want to save my brain from working".

Later on in the lesson, as a result of several interactions with the teacher and some involvement with one of the researchers, Amy and Sarah were able to invent their own data sets and identify the median. Questions like "What do you mean by saying "changing the numbers around" " how do you know that it is right?" and suggestions like " take each of these examples and write another one, change the numbers and see if you can work it out there" facilitated the process.

Towards the end of the lesson both girls could do the same for the mean of a set of numbers . The teacher had asked them to read again the definition of mean and explain some basic concepts like "the sum of the numbers" and "the number of numbers" for a particular set of numbers: "When we say sum what do we mean? "How many numbers are they?" These questions helped Amy in particular to develop a strategy that she applied in any set of numbers to calculate the mean. In the next lesson when students were asked to offer their own examples for consideration by the rest of the class, Sarah was able to offer her own set of numbers and explain the ways to find the median.

Later in a meeting of the teachers and researchers, Sam referred to Sarah, saying "She is still saying 'I can't do mathematics, I will never be any good', and I have to say 'Well, you are our median expert, and, you know, you can do this"'.

\subsection{Emerging issues from the three episodes}

In Episode 1 we see a situation that Sam had described as "resistance", in the class as a whole, and on the part of Amy and Sarah particularly. Students resented being given 
detention. Some did not see how to use a dictionary. From the teacher's perspective there was a tension - he wanted to challenge these students, as with all students he taught. However, challenge should be appropriate to students' thinking and needs. So while he did not wish to resort to direct instruction and simple exercises (the kind of diet often offered to slow-learning pupils - Boaler \& Wiliam 2001) he had to learn what kinds of challenge could motivate and be accessible to these students. Students' reactions indicated that the homework challenge had not been appropriate at this time. The reasons given were lack of dictionaries at home; however, we see the reasons being more deeply rooted in the dichotomous expectations and experience of teacher and students. The students found it difficult to engage: the task did not motivate them and they could not see what it required. They had little sense of its purpose for the teacher and even when given a dictionary in the classroom, found its use beyond their experience and understanding.

In Episodes 2 and 3 Amy initially, and then both girls moved from apparent resistance in the beginning to more confident engagement by the end of the two episodes. They had a strong focus on what is "right", and getting the right answer seemed to be the object of their mathematical engagement. The teacher's opening up and closing down of challenge seemed to enable the students to be first of all aware of what was needed in the task, and then to gain confidence in their ability to succeed with the task. By the end of the three lessons the girls could write down by themselves a set of numbers and, without the help of the teacher, calculate the mean of this set. Sarah, particularly, moved from 'saving her brain' to becoming the class 'expert' on finding the median. So they 
succeeded in being 'right': whether they perceived their success in conceptual terms is doubtful.

Micro-analysis leaves us with many questions about the nature of students' response and lack of confidence and what was being achieved through the various levels of interaction and challenge. The teacher aimed to produce challenging tasks at an appropriate level for the students (matching sensitivity to challenge). However, for a number of reasons students could not respond to the homework task. These reasons were related both to the task itself and to social factors in the wider activity. The cards task seemed more accessible to students, and with associated interactions led to positive outcomes in terms of student achievement. We seek insights to the interrelationships here to inform developmental processes in teaching.

\section{Macro-analysis using an activity theory perspective: Highlighting tensions through the EMT}

Taking activity to mean the collective worlds of teacher and students acting together in teaching-learning in the statistics lessons, the table below sets out EMT elements for both teacher and students. We use a tabular form rather than the familiar triangle to allow details to be included. It is important to recognise that as well as data from the classroom we have considerable data relating to the teacher's thinking and intentions but relatively little relating to the pupils. Thus, elements in the pupils' column are to some extent conjectural rather than evidential. In the teacher's column details come from classroom observation data supported by data from discussions with the teacher during the project (both about the episode and about general aspects of schooling) and from our own understanding of the educational and school systems. 


\section{Table 1: EMT analysis relating to Episode 1}

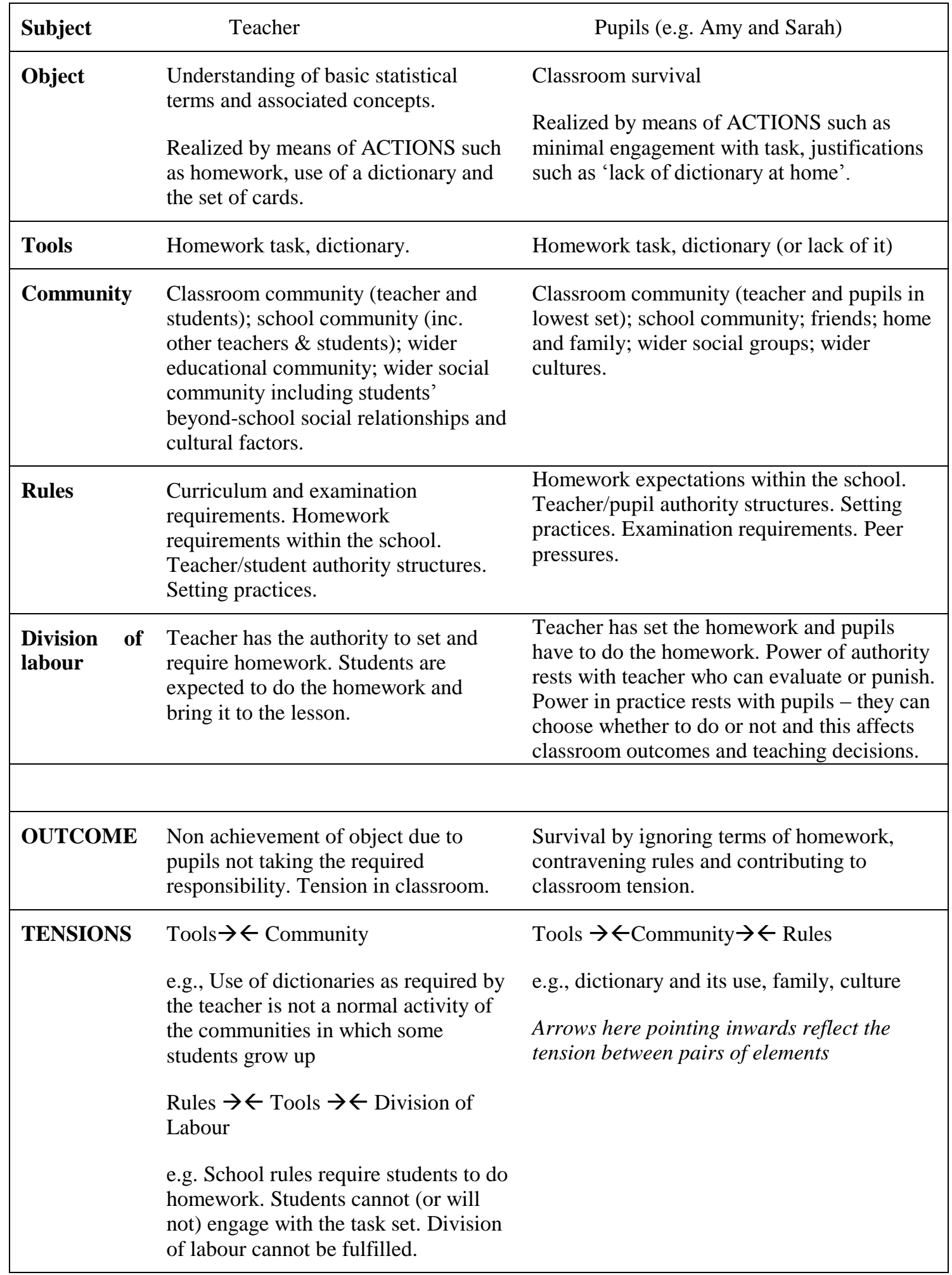


The table shows that key elements of the EMT lead to identification of (potential) key elements of the classroom activity system which highlight what we refer to as 'the homework dilemma'. Homework was a requirement of the school system, so, why had so many students not done the homework? This might relate to characteristics of communities such as home, friends, wider society who do not find it necessary to use dictionaries and libraries, or to look for information in a systematic way, or to have resources to do so. It might also reflect the teacher-student dichotomy mentioned earlier in which a task that appeared "challenging" to the teacher was neither motivational nor accessible to the pupils. Our conjectures are supported further by the teacher's later observations that Amy had similar difficulties with another task requiring her to find currency exchange rates from a newspaper.

We suggest elements of personal motivation or lack of it - inability through inertia - you can't immediately see what to do so you don't do anything. We see an ignoring of the school rules on homework, perhaps indicating that students do not see such rules as important to how they decide what to do in their lives ${ }^{4}$. The latter would fit with their vociferous objections to being given detention.

An EMT account highlights tensions as summarized in the last row of our table and are indicated by the symbol $\rightarrow \leftarrow$ between elements. We see here tensions between school rules which teachers and students are expected to follow and the nature of the homework task which seems fair to the teacher but with which students cannot or will not engage. The dictionary task is reasonable from a teacher's perspective within logico-

\footnotetext{
4 There is a growing literature relating to the concept and nature of homework, especially for low achieving pupils (see for example, Chazan, 2000) However, a deeper analysis relating to the homework issue is beyond the scope of this paper.
} 
mathematical and didactical communities; however within student peer and family communities it is strange and unreasonable. School rules can be seen as alien to student communities, so that when asked to engage with a task that seems to them strange and unreasonable, students ignore the school rules (possibly their only realistic option) and so risk punishment within the school system.

Tensions as expressed here point very clearly towards the mediating tool, that is the homework task, as central to the tensions arising. For students in this lower achieving set, however, communities, rules and division of labour figure strongly in their responses to tasks and apparent achievement in mathematics. Even if they are willing to engage with the teacher's challenge, their inability to do so for socially-rooted reasons places them in defiance of school rules and open to resulting sanctions. It is hardly surprising that they are resentful of being faced with sanctions and resistant to the teacher's challenges.

The teacher was determined to challenge the students towards a higher level of achievement in mathematics, rather than collude with them in underachievement. From his perspective as a dedicated mathematician and creative teacher, the tasks he designed were rooted in sincere didactic and pedagogic principles. He said,

... they are used to deal with things in very small discrete chunks, it is very difficult to teach mathematics in that kind of way. I always want to try developing something. However, he was aware himself of a need for more sensitivity towards students' possibility to respond to challenge, and, in the homework task we suggest he not only overestimated what these students were able to achieve, but also needed a deeper awareness of the macro factors. These include the requirement for homework, families 
that do not have dictionaries, students' lack of familiarity with dictionaries, students' lack of motivation, teachers' and students' alternative ways of seeing the classroom encounter.

What becomes evident as we analyse further, taking in Episodes 2 and 3, is that the teacher modified the nature of his challenge in relation to his growing awareness, within the project, of the macro-perspective and ways in which it influenced students' possibilities for response to his challenge. Table 2 represents this new situation. 


\section{Table 2: EMT analysis relating to Episodes 2 and 3}

\begin{tabular}{|c|c|c|}
\hline Subject & Teacher & Pupils (e.g. Amy and Sarah) \\
\hline \multirow[t]{2}{*}{ Object } & $\begin{array}{l}\text { Understanding of basic statistical } \\
\text { terms and associated concepts. }\end{array}$ & $\begin{array}{l}\text { Classroom survival, and success in terms of } \\
\text { right answers. }\end{array}$ \\
\hline & $\begin{array}{l}\text { Realized by means of ACTIONS such } \\
\text { as providing dictionaries and the cards } \\
\text { task, and modifying challenge to } \\
\text { engage the students. }\end{array}$ & $\begin{array}{l}\text { Realized by means of ACTIONS such as use } \\
\text { of the dictionary, positive engagement with } \\
\text { the cards task, interacting with the teacher } \\
\text { positively }\end{array}$ \\
\hline Tools & $\begin{array}{l}\text { Dictionaries in the classroom; sets of } \\
\text { cards and the associated card task. }\end{array}$ & $\begin{array}{l}\text { Dictionaries in the classroom; sets of cards } \\
\text { and the associated card task. }\end{array}$ \\
\hline Community & $\begin{array}{l}\text { Classroom community (teacher and } \\
\text { students); school community (inc. } \\
\text { other teachers \& students); wider } \\
\text { educational community; wider social } \\
\text { community including students' } \\
\text { beyond-school social relationships and } \\
\text { cultural factors. }\end{array}$ & $\begin{array}{l}\text { Classroom community (teacher and pupils in } \\
\text { lowest set); school community; friends; home } \\
\text { and family; wider social groups; wider } \\
\text { cultures. }\end{array}$ \\
\hline Rules & $\begin{array}{l}\text { Curriculum and examination } \\
\text { requirements. Homework } \\
\text { requirements within the school. } \\
\text { Teacher/student authority structures. } \\
\text { Setting practices. Social inhibitions } \\
\text { restricting opportunity. }\end{array}$ & $\begin{array}{l}\text { Homework expectations within the school. } \\
\text { Teacher/pupil authority structures. Setting } \\
\text { practices. Examination requirements. } \\
\text { Teacher's support towards engagement in } \\
\text { challenge. }\end{array}$ \\
\hline $\begin{array}{l}\text { Division of } \\
\text { labour }\end{array}$ & $\begin{array}{l}\text { Teacher has the authority to set tasks } \\
\text { and require engagement. Students are } \\
\text { expected to engage with the substance } \\
\text { of the lesson. Teacher must } \\
\text { accommodate to students needs and } \\
\text { possibilities. }\end{array}$ & $\begin{array}{l}\text { Teacher has provided tasks and students have } \\
\text { to engage with tasks. Power of authority rests } \\
\text { with teacher who can evaluate or punish, but } \\
\text { also challenge, support and encourage. Power } \\
\text { in practice rests with students - they can } \\
\text { choose how to respond which affects } \\
\text { classroom outcomes and teaching decisions. }\end{array}$ \\
\hline OUTCOME & $\begin{array}{l}\text { Some evidence of achievement of } \\
\text { object }\end{array}$ & $\begin{array}{l}\text { Evidence of some success in engagement } \\
\text { with tasks, making survival more comfortable } \\
\text { and even enjoyable. }\end{array}$ \\
\hline
\end{tabular}

The main differences here were firstly the cards task, focusing on definitions and

examples and aiming directly at an understanding of concepts behind the statistical terms;

secondly the teacher's modified approach. The cards task was for use in the classroom, so

could be mediated by the teacher in interaction with the students. In contrast with the

dictionary task, the card task was accessible for students who succeeded in linking 
definitions and examples. The teacher saw through this some indications of conceptual understanding.

In Table 1 we highlighted tensions within the teacher's and the students' activity systems. In addition, divergence between the systems is very obvious, related as it is to the severe differences between teacher and students perceptions of the homework task. In Table 2 it seems as if teacher and students work harder at responding to each other's perspectives and through modification of approach, come closer to achieving their object. Students experience some success and enjoyment in their survival of the classroom and the teacher perceives some evidence of conceptual understanding of the mathematics in the lessons. In terms of the teaching triad we might speak of harmony between challenge and sensitivity (Potari \& Jaworski, 2002): the teacher's challenges are posed at an appropriate level for students to engage and achieve.

The EMT and the tables that are based on this model act as an interpretative tool with respect to a teaching event - a tool that tries to capture differing dimensions that frame teaching and learning mathematics. Thus they frame our analyses to allow us to make explicit possible relations that are crucial to achieving the desired outcome, students' learning of mathematics. As Engeström has pointed out, drawing attention to contradictions is powerful in exposing the elements between which problems are rooted. In Table 2, a more harmonious relation is indicated between teachers' object and students' object. Analysis here suggests that the mediating tools are no longer in tension with unchangeable aspects of the educational and social systems in which activity is located. The teacher's actions related to the challenges he faced from his students allowed some form of harmony to be achieved. 


\section{Discussion of the teaching approach and its development}

In these lessons the teacher wanted to create classroom norms/rules that would foster the kinds of engagement he wanted, such rules were not part of the students' experience in traditional communities or with usual divisions of labour — for example, students in low mathematics sets experiencing low level tasks devoid of interest and challenge (Boaler \& Wiliam, 2001). We recall here that the observations and interviews analysed were part of a developmental research project in which the teachers sought to use the teaching triad as a developmental tool in their teaching; in Sam's case with a focus on 'sensitivity to students'. Sam's approach was to design creative tasks which could engage students productively with the mathematics he wanted them to understand. Thus we might see the teacher's activity in terms of Leont'ev's three levels as in Table 3:

Table 3: Teacher activity related to Leont'ev's three levels

\begin{tabular}{|l|l|l|}
\hline Activity \& Motive & $\begin{array}{l}\text { Creating a classroom } \\
\text { environment with students }\end{array}$ & $\begin{array}{l}\text { To achieve conceptual } \\
\text { understandings of } \\
\text { mathematics }\end{array}$ \\
\hline Actions \& Goals & $\begin{array}{l}\text { Design of tasks in specific } \\
\text { areas of mathematics (e.g. } \\
\text { statistical concepts) and } \\
\text { their use with students. }\end{array}$ & $\begin{array}{l}\text { To engage pupils and enable } \\
\text { meaning making related to } \\
\text { the concepts in focus }\end{array}$ \\
\hline Operations and conditions & $\begin{array}{l}\text { Use of } \\
\text {-- Homework } \\
\text {-- Dictionaries } \\
\text {-- Cards }\end{array}$ & $\begin{array}{l}\text { Expectations of independent } \\
\text { ork; levels of support and } \\
\text { challenge in interactive } \\
\text { situations }\end{array}$ \\
\hline
\end{tabular}

The developmental nature of activity can be seen in the teacher's own learning through critical reflection using the teaching triad. As the lessons proceeded and he became aware of student perceptions, for example seeing the dictionary as a French 
dictionary, his own approach was modified. The data here cannot show this easily, but we contrast with the approaches he used with his other classes. His way of working with Amy on 'mode' and 'median' included elements of direct instruction, telling and explaining, that were much less common in his other classes where he would mainly leave students with questions challenging their own thinking. Nevertheless, he praised Amy when elements of her own thinking were visible, sensitive perhaps to nurturing a more thoughtful approach to the mathematical concepts. These actions on the part of the teacher are related to a growing sensitivity to the needs of students in this lower set.

The students need motives to get involved in the tasks set by the teacher, something which, as Leont'ev (1979) and Engeström (1998) point out, is a crucial driving force behind the actions of students and teachers which determines the relation between the subject and the object in the EMT. In our case, possibly, the students' motives are too far from the teacher's expectations or wishes. Although our data on student perspectives is rather limited, one interview with Amy and Sarah, just after the three lessons is revealing. They were asked by the researcher "How do you feel in this class": their replies included, "easier to work, meet your friends. Mr Denver is a good teacher, he gives you a chance, if you don't understand, he'll explain to you". When the researcher asked about their "resistance" in the classroom, responses included,

You want some things, he wants other things, doing it for too long - boring, don't like it when you can't do it and he just goes on and on at you, if you get it wrong you're worried what everyone else will think.

When asked "What do you think about the maths", they responded with further comments on the teacher: "[We] like Mr Denver because he explains in different ways, 
unlike other teachers; [he] jokes, [uses] little games or something, he's nice, quite good at teaching”.

If I'm in a grumpy mood, I don't get on with him - he doesn't like that. He'll shout at you if you don't do the homework. He should ask us how much time we think we need for a piece of work.

Students talk about affective factors: meeting friends, the niceness, jokiness of the teacher, being worried about what others in the class will think if they get something wrong. Their remarks suggest that they recognise the teacher's efforts to help them to understand but at the same time his lack of appreciation of students' own feelings.

Sam recognized such motivational issues and their relation to particular students when he compared his teaching in Y10 (the lowest set) with that in Y12 (a top set).

Year 10 could get bored, they get off task, things could happen in there, things could happen in exactly the same way with my year 12 class but the consequences would be different, I feel. The consequences with my year 12 class would be disruptive behaviour and noise; the consequences of my year 10 class would be boredom and a kind of 'this is pointless'.

So, it is clear that the teacher is aware of differences between groups of students and the need for different approaches for different groups. His actions in designing the homework task were related to his learning goals for these students, and his own wide experience of using tasks to promote conceptual learning. His goals went beyond the particular mathematical concepts, in focus, to concerns in cross-curricular linkage through development of wider study skills.

...those kind of skills [using a dictionary for example] I think are skills right the way across the board. So I'll keep on setting homework like that because I think it's good for them to realise that they can have sources of information outside of what happens in the lesson. 
However, the teacher needed to meet also the students' affective needs in the interaction in the classroom so that the students themselves could conceive the object of the activity.

In this case, the challenge in the homework task was too far removed from what some students were able or willing to achieve. Could this have been clear to the teacher in the planning stage? Sam thought it was an easy task, from a cognitive point of view, and therefore could not believe the students had been unable to do it. Thus their 'resistance' must be due to other factors. In giving detention he indicated his own point of view of the nature of these factors, presumably not seeing the social, cultural and emotional factors that may have played a major role. This reflects a need for deeper sensitivity in appreciation of what is possible for the students, or how much help they might need to achieve teaching objectives. We point here to a need for a broader knowledge that takes into account the macro factors we have suggested above and is not specifically related to particular students, what we might call here a 'social sensitivity'.

Mellin Olsen (1987, p. 35) writes:

The whole point for the educator to recognise now, and to take advantage of, is that whatever she observes of learning behaviour by her pupils, the behaviour is part of some Aactivity, and she has to learn what this Activity is about in order to create a constructive encounter between this Activity and the various educational tasks she can provide. (Emphasis in original)

In the Teaching Triad Project, the four of us were educators, although only the two teachers had responsibility towards pupils. The two of us, authors of this paper, are the ones making an activity theory analysis from which we learn much about the nature of mathematical challenge and sensitivity to students in relation to classroom Activity (to use Mellin Olsen's A discriminant). In his engagement with the teaching triad, the 
teacher, Sam, came to reflect on the nature of sensitivity and its relation to the resistance of his students. As part of this project, he came to appreciate more about the Activity and how it related to his tasks. A longer term study would be needed to find out if this would influence his future task design. Being alerted to tensions, above, draws attention to the so-called unchangeable factors which include school and educational systems.

Recognition of student dispositions and the kinds of tasks they find accessible or motivating can highlight for schools and teachers the possibility that student grouping structures within a school may not afford the best environment for students' achievement. Social sensitivity goes beyond teacher awareness to a whole school responsibility.

A final point concerns a relationship between activity theory and development in teaching-learning. For the teacher to learn more about Activity "in order to create a constructive encounter between this Activity and the various educational tasks she can provide" (Mellin Olsen, above), some kinds of mediating action is required. We suggest that the Teaching Triad project itself acted as a mediating tool and that Activity in the project could be seen to create developmental opportunities for Activity in the classroom. Through the project the teachers learned to develop their task design and classroom interactions, while the university researchers learned to theorise the developmental process.

\section{References}

Abboud-Blanchard, M., Cazes, C. \& Vandebrouck, F. (2007). Teachers' activity in exercises-based lessons: Some case studies. In D. Pitta- Pantazi \& G. Philippou (Eds.). Proceedings of the Fifth Congress of the European Society for Research in Mathematics Education (pp. 1827-1836). Cyprus: University of Cyprus. 
Bartolini Bussi, M. G. (1998). Verbal interaction in the mathematics classroom: A Vygotskian analysis. In H. Steinbring, M. G. Bartolini Bussi, \& A Sierpinska (Eds.). Language and communication in the mathematics classroom (pp. 65-84). Reston, Va: National Council of Teachers of Mathematics.

Boaler, J. \& Wiliam, D. (2001), 'We've still got to learn!' Student's perspectives on ability grouping and mathematical achievement. In P.Gates (ed.) Issues in Mathematics Teaching (pp. 77-92). . London: Routledge.

Chazan, D. (2000). Beyond formulas in mathematics and teaching: Dynamics of the high school algebra classroom. NY: Teacher's College Press.

Christiansen, B. \& Walther, G. (1986). Task and Activity. In B. Christiansen, B. Howson \& M. Otte (Eds.), Perspectives on Mathematics Education (pp. 243-307). Dordrecht: Reidel.

Cobb, P., Yackel, E. and Wood, T. (1992). Interaction and learning in mathematics classroom situations. Educational Studies in Mathematics 23, 99-122.

Cole, M. \& Engeström, Y. (1993). A cultural-historical approach to distributed cognition'. In Salomon, G. (ed.), Distributed Cognitions: Psychological and Educational Considerations (pp. 1-46). New York: Cambridge University Press.

Daniels, H. (2001). Vygotsky and Pedagogy. London: Routledge Falmer.

Engeström, Y. (1998). Reorganising the motivational sphere of classroom culture: an activity-theoretical analysis of planning in a teacher team. In F. Seeger, J. Voigt, \& U. Waschescio, (Eds.), The Culture of the Mathematics Classroom (pp. 76-103). Cambridge: Cambridge University Press. 
Engeström, Y. \& Cole, M. (1997). Situated cognition in search of an agenda. In J. A.

Whitson, \& D. Kirshner, (Eds.), Situated Cognition. Social, semiotic, and psychological perspectives (pp. 301-309) . Hillsdale, NJ: Lawrence Erlbaum.

Jaworski, B. (1994). Investigating Mathematics Teaching: A Constructivist Enquiry. London: Falmer Press.

Jaworski, B. (1998). Mathematics teacher research: process, practice and the development of teaching. Journal of Mathematics Teacher Education 1, 3-31.

Jaworski, B., \& Goodchild, S. (2006). Inquiry community in an activity theory frame. In J. Navotná, H. Moraová, M. Krátká and N. Stehliková (Eds.), Proceedings of the $30^{\text {th }}$ Conference of the International Group for the Psychology of Mathematics Education,(Vol. 3, pp.353-360). Prague: Charles University.

Kieran, C., Forman, E. \& Sfard, A. (2001). Bridging the individual and the social: Discursive approaches to research in mathematics education . Educational Studies in Mathematics 46, 1-3.

Leont'ev, A. N. (1979). The problem of activity in psychology. In J. V. Wertsch (Ed.), The concept of activity in Soviet psychology (pp. 37-71). New York: M. E. Sharpe.

Lerman, S. (1996). Intersubjectivity in mathematics learning: A challenge to the radical constructivist paradigm. Journal for Research in Mathematics Education 27, 133 150.

Lerman, S. (2001). Cultural, discursive psychology: a sociocultural approach to studying the teaching and learning of mathematics. Educational Studies in Mathematics 46, 87113. 
Lerman, S., Xu, G. \& Tsatsaroni, A. (2002). Developing Theories of Mathematics Education Research: The ESM story'. Educational Studies in Mathematics 51, 23-40.

Mellin Olsen, S. (1987). The Politics of Mathematics Education. Dordrecht: D. Reidel.

Potari, D and Jaworski, B. (2002). Tacking complexity in mathematics teaching development: Using the teaching triad as a tool for reflection and analysis. Journal of Mathematics Teacher Education 5, 351-380.

Seeger, F., Voigt, J. \& Waschescio, U. (1998). The Culture of the Mathematics Classroom. Cambridge: Cambridge University Press.

Steinbring, H. (1998). Elements of epistemological knowledge for mathematics teachers. Journal of Mathematics Teacher Education 1, 157-189.

Valero-Dueñas, P. X. (2002). Reform, Democracy and Mathematics Education: Towards a socio-political frame for understanding change in the organisation of secondary school mathematics. Unpublished PhD thesis. The Danish University of Education, Denmark.

Van Oers, B. (2001). Educational forms of initiation in mathematical culture. Educational Studies in Mathematics 46, 59-85.

Voigt, J. (1996). Negotiation of mathematical meaning in classroom processes: social interaction and learning mathematics, in L. P. Steffe, P. Nesher, P. Cobb, G. A. Goldin, G. A. \& B. Greer, (Eds.) Theories of Mathematical Learning (pp. 21-50). Mahwah, NJ: Lawrence Erlbaum Associates.

Wertsch, J. V. \& Lee, B. (1984). The multiple levels of analysis in a theory of action. Human development 27, 193-196. 
Wertsch, J. V., del Rio, P. \& Alvarez, A. (1995). Sociocultural studies: History, action and mediation. In J. V. Wertsch, P. del Rio, \& A. Alvarez, (Eds.), Sociocultural Studies of the Mind(pp. 1-34). Cambridge: Cambridge University Press. 
Appendix 1: One set of cards for the task on averages given in Sam's lesson.

Card 1: The sum of the numbers divided by the number of numbers.

Card 2: The middle number after the numbers have been aranged in order of size.

Card 3: One item or number that represents the whole group.

Card 4: The most popular item or the item that occurs the most often.

Card 5: The ... of 2,4,1,3,4,1,5 is 4 because the highest number is 5 and the lowest is 1.

Card 6: $\quad$ The $\ldots$ is $5-1=4$.

Card 7: The difference between the highest and lowest number.

Card 8: The $\ldots$ of 2,0,1,3,4,1,5 is 1 because there are more 1's than any other item.

Card 9: The $\ldots$ of $1,4,3,0,1,2,1,4$ is $(1+\ldots+4) \div 8=16 \div 8=2$.

Card 10: The ... of 2,0,1,3,4,1,5 is found from $0,1,1,2,3,4,5.2$ is the ... because it's in the middle.

Card 11: The ... of 2,0,1,3,4,1,5,3 is found from $0,1,1,2,3,3,4,5.2$ and 3 are both in the middle so the ... is $21 / 2$.

The above set of cards emphasized the definition of the statistical terms (cards 1,2, $3,4,7$ ), and the process through examples of calculating the specific averages (cards 5, 6 , $8,9,10,11)$. The students had to build meaning of the statistical terms by linking the verbal symbol, the definition and the example. 